\title{
Genetic Polymorphism of Cytochrome p450 (2C9) Enzyme in Iranian Baluch Ethnic Group
}

\author{
Mojdeh Ghiyas Tabari ${ }^{1}$, Fatemeh Naseri $^{2}$, Maryam Agh Ataby ${ }^{3}$ and Abdoljalal Marjani ${ }^{4, *}$
}

${ }^{1}$ Babol University of Medicine Sciences, Babol, Mazandaran province, Iran; ${ }^{2}$ Chabahar-Sistane and Baluchestan Prov-
ince, Iran; ${ }^{3}$ Fatima Alzahra Hospital Minodasht, Golestan University of Medical Sciences, Gorgan, Golestan Province,
Iran; ${ }^{4}$ Department of Biochemistry and Biophysics, Metabolic Disorders Research Center, Gorgan Faculty of Medicine,
Golestan University of Medical Sciences, Gorgan, Golestan province, Iran

\begin{abstract}
The aim of the present study is to assess and compare the frequencies of the cytochrome P450 CYP2C9 variations in the Baluch ethnic group $(\mathrm{n}=110)$ with other ethnic groups. The allele frequencies of CYP2C $9 * 1, \mathrm{CYP} 2 \mathrm{C} 9 * 2$ and CYP2C9*3 were $80.90 \%, 11.82 \%$ and $7.27 \%$, respectively. $70.90 \%, 11.82 \%, 8.18 \%, 4.55 \%, 2.73 \%$ and $1.82 \%$ of subjects were with CYP2C $9 * 1 / * 1$, CYP2C $9 * 1 / 22$, CYP2C $9 * 1 / * 3$, CYP 2 C $9 * 2 * 2$, CYP 2 C $9 * 2 * 3$ and CYP2C $9 * 3 / * 3$ genotypes, respectively. Different mutants may effect on prediction of drug dose requirements in different ethnic groups. Thus, CYP2C9 variants to be determined for findings high risk groups use optimal dosage of drugs metabolized by this polymorphic enzyme.
\end{abstract}

Keywords: Baluch ethnic group, CYP2C9 genetic polymorphism, polymerase chain reaction-restriction fragment length polymorphism (PCR-RFLP).

\section{INTRODUCTION}

The cytochrome P-450 (CYP) is responsible for the metabolism of many drugs, such as warfarin, phenytoin, losartan, irbesartan, tolbutamide, glipizide, torsemide, and different nonsteroidal anti-inflammatory drugs [1]. Various single nucleotide genetic polymorphisms for CYP2C9 have been recognized $[2,3]$. There are 3 alleles, (CYP2C $9 * 1$ (wild-type allele), $* 2$ and $* 3$ ) in most different ethnic groups. People with the $* 2$ and $* 3$ alleles show decreased enzymatic activity, and these subjects have been indicated as "poor metabolizers" $[4,5]$ that they may tolerate drug toxicity. Therefore, it is necessary to determine CYP2C9 genotype in different ethnic groups to prevent drug toxicity. Study on the genotype distribution among Caucasian populations varies for the $* 1 / * 1, * 1 / * 2 * 1 / * 3 *, 2 / * 2, * 2 / * 3$ and $* 3 / * 3$ genotypes [2]. Caucasians populations have shown more allele frequencies of CYP2C9*2 and CYP2C9*3 when compared to AfricanAmerican and Asian populations while Chinese and Japanese have not indicated the CYP2C9*2 allele [6]. There has not been any investigation on the genotype of CYP2C9 allelic variants in Baluch ethnic group in Iran. Different studies have shown that there are variation in the distribution of polymorphic alleles of CYP2C9 between Iranian ethnic groups in North and South of Iran. These studies have indicated that the frequency of $\mathrm{CYP} 2 \mathrm{C} 9 * 3$ among southern Iranians $(9.8 \%)$ and Caucasians $(9.7 \%)$ were similar. The frequency of CYP2C9*3 among Africans (1\%), Japanese (2.3\%), and

\footnotetext{
*Address correspondence to this author at the Department of Biochemistry and Biophysics, Metabolic Disorders Research Center, Gorgan Faculty of Medicine, Golestan_University of Medical Sciences, Gorgan, Golestan province, Iran. Tel: +98(171)4421651; Fax: +98(171)4440225;

E-mail: abdoljalal@yahoo.com
}

northern Iranians $(0 \%)$ were lower than southern Iranians [7]. Study of Azarpira et al. also showed that the frequency of CYP2C $* 2(25.3 \%)$ was higher than Caucasian $(10 \%-$ $13 \%)$, African (2\%), and Asian (0\%) populations [7]. The aim of the study was to assess and compare the frequencies of the cytochrome P450 CYP2C9 alleles and genotypes in the Baluch ethnic group with the frequencies in other different ethnic groups.

\section{MATERIALS AND METHODS}

The present study contained 110 unrelated healthy Baluch people (who speak Baluch as a native language and population inbreeding people) referred to Health Center in Chabahar, in Sistan and Baluchestan province (located in South East of Iran). The age ranges of Baluch ethnic group was 14-53 years old. The mean ages of subjects were 30/76 $\pm 11 / 63$ years old. A five milliliters venous blood was collected into EDTA tubes. DNA extraction from peripheral white blood cells was carried out by the method of salting out [8]. Sterilized distilled water was used to dissolve DNA extract and samples were stored in $-20{ }^{\circ} \mathrm{C}$ until analyzed by polymerase chain reaction (PCR). Genotyping of CYP2C9 alleles was done by Polymerase Chain Reaction (PCR)Restriction Fragment Length Polymorphism (RFLP) technique [9]. The PCR was performed in a 25 microliter reaction mixture containing PCR buffer $(2.5 \mu \mathrm{l}(10 \mathrm{mM}$ Tris$\mathrm{HCl}, \mathrm{pH} 9), 2 \mu \mathrm{l}(40 \mathrm{Mm}) \mathrm{MgCl} 2$ (Fermentas), $50 \mathrm{mM} \mathrm{KCl}$ (Fermentas), $12.5 \mathrm{mM}$ deoxyribonucleotide triphosphate (dNTP) mix, $0.2 \mu \mathrm{l}(5 \mathrm{U} / \mu \mathrm{l}) \mathrm{Taq}$ polymerase (Fermentas), 1 $\mu \mathrm{l}(0.4 \mu \mathrm{M})$ of each primer (Bioneer), $2 \mu \mathrm{l}(100 \mathrm{ng} / \mu \mathrm{l})$ DNA (Genomic) and sterile distillated water). Genetix CG palmthermocycler (India) was used to perform PCR. Restriction enzymes (Fermentas) were utilized to digest PCR products 
$(10 \mu 1)$. Restriction enzymes, Ava II and Kpn I were used for CYP2C9*2 and CYP2C9*3 at $37 \mathrm{oC}$ for $16 \mathrm{hrs}$ for complete digestion. Amplification of primers was done by De Morais et al. method [10]. Electrophorese is of the DNA fragments (Apelex, France) was performed on a 3\% agarose gel and Ethidium bromide was utilized to stain the gel. Detected Bands were photographed using a Polaroid Gel Camera with black and white film (not shown). For detection of the CYP2C $9 * 2$ mutation, sense primer (5'CACTGGCTGAAAGAGCTAACAGAG-3') and antisense primer (5'-GTGATATGGAGTAGGGTCACCCAC-3') were used. The CYP2C $9 * 3$ mutation detection was done using sense primer 5'-TGCACGAGGTCCAGAGGTAC-3' and antisense primer 5'-ACAAACTTACCTTGGGAATGAGA3'. The conditions of PCR amplification were as follows: For CYP2C9*2: Initial denaturation, Number of cycle(s), Denaturation, annealing, Extention and final extention step were $95^{\circ} \mathrm{C}, 10 \mathrm{~min}$.; $40 ; 95^{\circ} \mathrm{C}, 5 \mathrm{sec}$; $65^{\circ} \mathrm{C}, 30 \mathrm{sec}$.; $72^{\circ} \mathrm{C}, 30$ sec. and $72^{\circ} \mathrm{C}, 5 \mathrm{~min}$. and for $\mathrm{CYP} 2 \mathrm{C} 9 * 3: 94^{\circ} \mathrm{C}, 5 \mathrm{~min}$; 30 ; $94{ }^{\circ} \mathrm{C}, 45 \mathrm{sec}$.; $63{ }^{\circ} \mathrm{C}, 45 \mathrm{sec}$.; $72{ }^{\circ} \mathrm{C}, 30 \mathrm{sec}$. and $72^{\circ} \mathrm{C}, 5 \mathrm{~min}$., respectively. $95 \%$ confidence intervals $(95 \% \mathrm{CI})$ were performed to determine the frequency of the variant alleles of each gene. Fisher exact test was used to evaluate variations in allele and genotype frequencies between Baluch ethnic groups and different other population.

\section{RESULTS}

The distribution of genotype and allelic frequencies of CYP2C9 among Baluch ethnic group are shown in Table $\mathbf{1 .}$ The allele frequency of CYP2C $9 * 1$ (Wild type), CYP2C $9 * 2$ and CYP2C9*3 were $80.90 \%$ (95\% CI: $73.55-88.24)$, $11.82 \%$ (95\% CI: $5.78-17.82)$ and $7.27 \%$ (95\% CI: $2.44-$ 12.16), respectively (Table 1). The frequencies of CYP2C9 genotypes in Baluch ethnic group were found to be $70.90 \%$ of subjects with CYP2C9*1/*1 genotype (95\% CI: 62.41 79.38). $11.82 \%, 8.18 \%, 4.55 \%, 2.73$ and 1.82 subjects with CYP2C $9 * 1 / * 2$ (95\% CI: 5.78-17.84), CYP2C $9 * 1 / * 3(95 \%$ CI: $3.06-13.30), \quad$ CYP2C $9 * 2 / * 2(95 \% \quad$ CI: $0.65-8.43)$, CYP2C $9 * 2 / * 3$ (95\% CI: 0-5.77) and CYP2C $9 * 3 / * 3(95 \%$ CI: 0-4.30) genotypes, respectively (Table 1). Tables 2 and 3 show the distribution of CYP2C9 genotype and allele frequency in Baluch ethnic group and in different populations.

\section{DISCUSSION}

Variations in CYP expression among different ethnic groups make it important in drug response, activity and detoxification. It is been shown that there are three major variants of the CYP2C9 gene in different ethnic groups. It is reported that there are three major variants of the CYP2C9 gene in Caucasian populations [11]. CYP2C9*2 and CYP $2 C 9 * 3$ allelic variants show almost $10-40 \%$ and $5-15 \%$ of the activity of $C Y P 2 C 9 * 1$ for various drug, respectively [12-15]. The allelic frequency of CYP2C9*2 found in the present study was $11.82 \%$ (almost similar to the Iranian Fars) [16] which was higher than Japanese [24], African [25], Pakistanis [26], Tamilians [27], Keralans [28], Chinese [29] and Korean [30] populations (Table 2). Our results show that the CYP2C9*2 variant was more frequent than above mentioned populations. In our study group, the allelic frequency of CYP2C9*3 was $7.27 \%$. The frequency of CYP $2 C^{*} 3$ was almost similar to the frequencies found in Italians [17], Greeks [18], Swedish [20], Pakistanis [26] and Keralans [28] (Table 2). Genetic differences in the CYP2C9 make it possible that some drugs such as warfarin metabolize differently. Single-nucleotide polymorphisms in CYP2C9 influence metabolism of this drug. Clinicians can appraise optimal warfarin dose by genotyping subjects for singlenucleotide polymorphisms. Subjects who have the CYP2C9*2 and/or CYP2C9*3 variants metabolize warfarin more in a different manner than subjects without these variants. It has been shown that CYP2C9 genotype estimates warfarin optimal dosage in subjects on warfarin treatment [30]. Distribution of CYP2C9 genotypes in Baluch and different ethnic groups has been shown in Table 3. Our genotype results have shown that frequency of $* 1 / * 2$ and $* 1 / * 3$ was $11.82 \%$ and $8.18 \%$ which was higher [24-30] and lower [16-21, 23 and 26-28] than other populations, respectively. The prevalence of CYP2C $9 * 2 / * 2$ (except Iranian Turkmen $[16]), * 2 / * 3$ and $* 3 / * 3$ genotypes in Iranian Baluch ethnic group were higher when compared with different other ethnic groups [16-30]. Many studies have indicated that $2 / * 2$ $[24-29,6], * 2 / * 3[16,22-29$ and 6$]$ and $* 3 / * 3[16,18,21,22$, 25,27 and 29,6] genotype frequency was not detectable in some populations. CYP2C $9 * 3 / * 3$ genotype is contributed with some important clinical variations in the pharmacokinetics of CYP2C9 substrates.

Table 1. Genotype and Allelic frequencies of CYP2C9 in the Baluch ethnic group.

\begin{tabular}{|c|c|c|c|c|c|}
\hline CYP2C9 genotypes & Number (\%) & $95 \% \mathrm{CI}$ & CYP2C9 alleles & Number (\%) & $95 \%$ CI \\
\hline$* 1 / * 1$ & $78(70.90)$ & $62.41-79.38$ & $* 1$ & $89(80.90)$ & $73.55-88.24$ \\
\hline$* 1 / * 3$ & $9(8.18)$ & $3.06-13.30$ & $* 3$ & $8(7.27)$ & $2.44-12.16$ \\
\hline$* 2 / * 2$ & $5(4.55)$ & $0.65-8.43$ & & & \\
\hline$* 3 / * 3$ & $2(1.82)$ & $0-4.30$ & & & \\
\hline Total & $110(100)$ & & & & \\
\hline
\end{tabular}

*Means separation of effective alleles. 
Table 2. Comparison of allele frequencies of CYP2C9 in Baluch ethnic group with different populations.

\begin{tabular}{|c|c|c|c|c|c|}
\hline Population study & $\begin{array}{l}\text { Sample size } \\
\text { (n) }\end{array}$ & $\begin{array}{l}\text { Allele frequency of } \\
\qquad 1(\%)\end{array}$ & $\begin{array}{c}\text { Allele frequency of } \\
* 2(\%)\end{array}$ & $\begin{array}{l}\text { Allele frequency of } \\
\qquad * 3(\%)\end{array}$ & References \\
\hline Iranian Baluch & 110 & 80.90 & 11.82 & 7.27 & Present study \\
\hline Iranian Fars & 140 & 83 & $11(\mathrm{NS})$ & $6(\mathrm{NS})$ & 16 \\
\hline Iranian Turkmen & 140 & 88 & $8(\mathrm{NS})$ & $4(\mathrm{NS})$ & 16 \\
\hline Greek & 283 & 79 & $12.8(\mathrm{NS})$ & 8.1(NS) & 18 \\
\hline Russians & 290 & 82.7 & $10.5(\mathrm{NS})$ & $6.7(\mathrm{NS})$ & 19 \\
\hline Swedish & 430 & 81.9 & $10.6(\mathrm{NS})$ & 7.4(NS) & 20 \\
\hline Slovenia & 129 & 81.7 & $12(\mathrm{NS})$ & $6.2(\mathrm{NS})$ & 21 \\
\hline African & 47 & 9 & $2(0.004)$ & $1(<0.0001)$ & 25 \\
\hline Pakistan & 120 & 91.6 & $0.8(0.001)$ & $7.5(\mathrm{NS})$ & 26 \\
\hline Tamilians & 135 & 90.7 & $2.6(0.0045)$ & $6.7(\mathrm{NS})$ & 27 \\
\hline Kerala & 120 & 90 & $2.0(0.0011)$ & $8.0(\mathrm{NS})$ & 28 \\
\hline Chinese & 115 & 98.3 & $0(0.001)$ & $1.7(<0.0001)$ & 29 \\
\hline Korean & 574 & 98.9 & $0(0.001)$ & $1.1(<0.0001)$ & 30 \\
\hline
\end{tabular}

Differences in the allele frequencies were determined by Fisher exact test. NS: No significant differences.

P-value versus Baluch ethnic group.

*Means separation of effective alleles.

Table 3. Comparison of CYP2C9 genotype frequency in Baluch ethnic group with different populations.

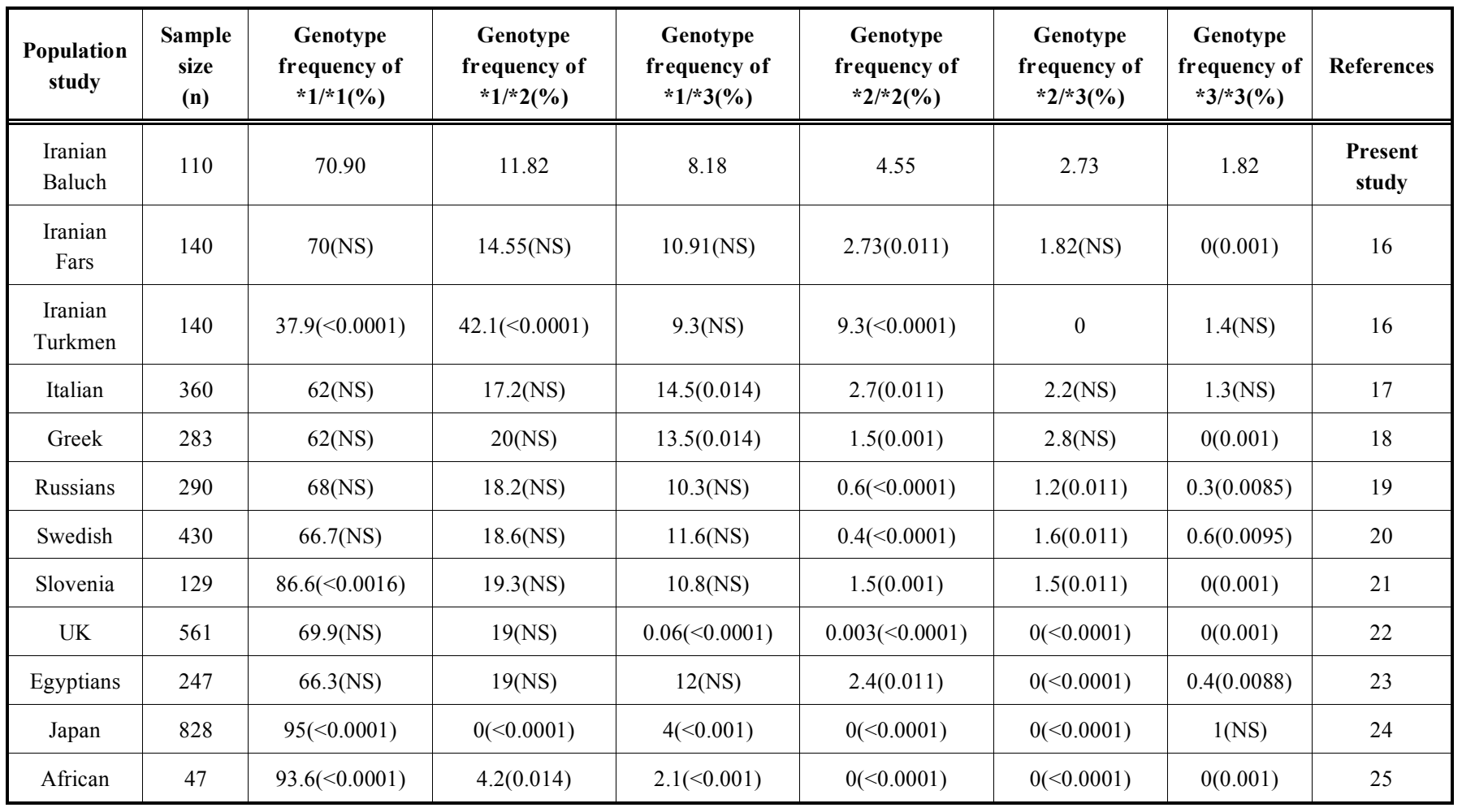


(Table 3) contd....

\begin{tabular}{|c|c|c|c|c|c|c|c|c|}
\hline $\begin{array}{l}\text { Population } \\
\text { study }\end{array}$ & $\begin{array}{c}\text { Sample } \\
\text { size } \\
\text { (n) }\end{array}$ & $\begin{array}{l}\text { Genotype } \\
\text { frequency of } \\
* 1 / * 1(\%)\end{array}$ & $\begin{array}{l}\text { Genotype } \\
\text { frequency of } \\
* 1 / * 2(\%)\end{array}$ & $\begin{array}{c}\text { Genotype } \\
\text { frequency of } \\
* 1 / * 3(\%)\end{array}$ & $\begin{array}{c}\text { Genotype } \\
\text { frequency of } \\
* 2 / * 2(\%)\end{array}$ & $\begin{array}{l}\text { Genotype } \\
\text { frequency of } \\
* 2 / * 3(\%)\end{array}$ & $\begin{array}{l}\text { Genotype } \\
\text { frequency of } \\
* 3 / * 3(\%)\end{array}$ & References \\
\hline Tamilians & 135 & 82.3(NS) & $4.4(0.017)$ & $12.7(\mathrm{NS})$ & $0(<0.0001)$ & $0.7(<0.0001)$ & $0(0.001)$ & 27 \\
\hline Kerala & 120 & $81.0(\mathrm{NS})$ & $4.0(0.011)$ & $14.0(0.014)$ & $0(<0.0001)$ & $0(<0.0001)$ & $1.0(\mathrm{NS})$ & 28 \\
\hline Korean & 574 & $97.7(<0.0001)$ & $0(<0.0001)$ & $2.3(<0.001)$ & $0(<0.0001)$ & $0(<0.0001)$ & $0(0.001)$ & 30 \\
\hline
\end{tabular}

Differences in the genotype frequencies were determined by Fisher exact test. NS: No significant differences. P-value versus Baluch ethnic group.

*Means separation of effective alleles.

\section{CONCLUSION}

In conclusion, our results show that there are ethnic variations in the $C Y P 2 C 9$ allele and genotype frequencies. Genetic differences in the CYP2C9 were seen in Iranian Baluch. The presence of different mutant genotypes and alleles may effect on prediction of drug dose requirements in different ethnic groups. Thus, it requires that CYP2C9 variants determination in different populations may help high risk groups to use optimal dosage of drugs metabolized by this polymorphic enzyme.

\section{CONFLICT OF INTEREST}

The authors confirm that this article content has no conflict of interest.

\section{ACKNOWLEDGEMENTS}

Declared none.

\section{REFERENCES}

[1] Lee, C.R.; Goldstein, J.A.; Pieper, J.A. Cytochrome P450 2C9 Polymorphisms: A comprehensive review of the in-vitro and human datam. Pharmacogenetics, 2002, 3, 251-263.

[2] Si, D.; Guo, Y.; Zhang, Y.; Yang, L.; Zhou, H.; Zhong, D. Identification of a novel variant CYP2C9 Allele in Chinese. Pharmacogenetics, 2004, 7, 465-469.

[3] Maekawa, K.; Harakawa, N.; Sugiyama, E.; Tohkin, M.; Kim, S., R.; Kaniwa, N.; Katori, N.; Hasegawa, R.; Yasuda, K.; Kamide, K.; Miyata, T.; Saito, Y.; Jun-ichi S. Substrate-dependent functional alterations of seven CYP2C9 variants found in Japanese subjects. Drug Metab. Disposit., 2009, 9, 1895-1903.

[4] Aithal, G. P.; Day, C.P.; Kesteven, P.J.; Daly, A.K. Association of polymorphisms in the Cytochrome P450 CYP2C9 with Warfarin dose requirement and risk of bleeding complications. Lancet, 1999, 9154, 717-719.

[5] Schwarz, U.I. Clinical relevance of genetic polymor-phisms in the human CYP2C9 Gene. Eur. J. Clin. Invest., 2003, 2, 23-30.

[6] Yoon, Y.R.; Shon, J.H.; Kim, M.K.; Lim, Y., C.; Lee, H., R.; Park, J., Y.; Cha, I-J.; Shin, J-G. Frequency of cytochrome P450 2C9 mutant alleles in a Korean population. Br. J. Clin. Pharmacol., 2001, 3, 277- 280 .

[7] Azarpira, N.; Namazi, S.; Hendijani, F.; Banan, M.; Darai, M. Investigation of allele and genotype frequencies of CYP2C9, CYP2C19 and VKORC1 in Iran. Pharmacol Rep., 2010, 62, 740746.

[8] Miller, S.A.; Dykes, D.D.; Polesky, H.F. A simple salting out procedure for extracting DNA from human nucleated cells. Nucleic Acids Res., 1988, 3, 1215.

[9] Brosen, K.; de Morais, S.M.; Meyer, U.A.; Goldstein, J.A. A multifamily study on the relationship between CYP2C19 genotype and S-mephenytoin oxidation phenotype. Pharmacogenetics., 1995, 5, 312-7.

[10] De Morais, S.M.; Wilkinson, G.R.; Blaisdell, J.; Meyer, U.A.; Nakamura, K.; Goldstein, J.A. Identification of a new genetic defect responsible for the polymorphism of (S)-mephenytoin metabolism in Japanese. Mol. Pharmacol., 1994, 4, 594- 598.

[11] Miners, J.O.; Birkett, D.J. Cytochrome P4502C9: an enzyme of major importance in human drug metabolism. Br. J. Clin. Pharmacol., 1998, 45, 525-38.

[12] Rettie, A.E.; Wienkers, L.C.; Gonzalez, F.J.; Trager, W.F.; Korzewka, K.R. Impaired (S)-warfarin metabolism catalysed by the R144C allele variant of CYP2C9. Pharmacogenetics., 1994, 4, 3942.

[13] Haining, R.L.; Hunter, A.P.; Veronese, M.E.; Trager, W.F.; Rettie, A.E. Allele variants of human cytochrome P450 2C9: baculovirusmediated expression, purification, structural characterization, substrate stereoselectivity, and prochiral selectivity of the wild-type and I359L mutant forms. Arch. Biochem. Biophys., 1996, 333, 44758 .

[14] Takanashi, K.; Tainaka, H.; Kobayashi, K.; Yasumori, T.; Hosakama, M.; Chiba, K. CYP2C9 Ile359 and Leu359 variants: enzyme kinetic study with seven substrates. Pharmacogenetics., 2000, 10 , 95-104.

[15] Thijssen, H.H.; Ritzen, B. Acenocumarol pharmacokinetics in relation to cytochrome P450 2C9 genotype. Clin. Pharmacol. Ther., 2003, 74, 61-8.

[16] Agh A.O.; Ghiyas T.R.; Mansourian, A.R.; Samai, N.M.; Marjani, A. Genetic polymorphism of cytochrome P450 2C9 (CYP2C9) in two ethnic groups in Iran. Am. J. Biomed. Sci, 2013, 3, 177-187.

[17] Scordo, M.G.; Caputi, A.P.; D’Arrigo, C.; Fava, G.; Spina, E. Allele and genotype frequencies of CYP2C9, CYP2C19 and CYP2D6 in an Italian population. Pharmacol. Res., 2004, 50, 195-200.

[18] Arvanitidis, K.; Ragia, G.; Iordanidou, M.; Kyriaki, S.; Xanthi, A.; Tavridou, A.; Manolopoulos, V.G. Genetic polymorphisms of drug-metabolizing enzymes CYP2D6, CYP2C9, CYP2C19 and CYP3A5 in the Greek population. Fundam. Clin. Pharmacol., 2007, 21, 419-426.

[19] Gaikovitch, E.A.; Cascorbi, I.; Mrozikiewicz, P.M.; Brockmöller, J.; Frötschl, R.; Köpke, K.; Gerloff, T.; Chernov, J.N.; Roots, I. Polymorphisms of drug-metabolizing enzymes CYP2C9, CYP2C19, CYP2D6, CYP1A1, NAT2 and of P-glycoprotein in a Russian population. Eur. J. Clin. Pharmacol., 2003, 59, 303-312.

[20] Yasar, U.; Eliasson, E.; Dahl, M.L.; Johansson, I.; IngelmanSundberg, M.; Sjöqvist, F. Validation of methods for CYP2C9 genotyping: frequencies of mutant alleles in a Swedish population. Biochem. Biophys. Res. Commun., 1999, 254, 628-631.

[21] Herman, D.; Dolzan, V.; Breskvar, K. Genetic polymorphism of cytochromes P450 2C9 and 2C19 in Slovenian population. Zdrav. Vestn., 2003, 72, 347-351.

[22] Sconce, E.A.; Khan, T.I.; Wynne, H.A.; Avery, P.; Monkhouse, L.; King, B.P.; Wood, P.; Kesteven, P.; Daly, A.K.; Kamali, F. The impact of CYP2C9 and $V K O R C 1$ genetic polymorphism and patient characteristics upon warfarin dose requirements: proposal for a new dosing regimen. Blood, 2005, 106, 2329-2333.

[23] Hamdy, S.I.; Hiratsuka, M.; Narahara, K.; El-Enany, M.; Moursi, N.; Ahmed, M.S.; Mizugaki, M. Allele and genotype frequencies of 
polymorphic cytochromes P450 (CYP2C9, CYP2C19, CYP2E1) and dihydropyrimidine dehydrogenase (DPYD) in the Egyptian population. Br. J. Clin. Pharmacol., 2002, 53, 596-603.

[24] Mushiroda, T.; Ohnishi, Y.; Saito, S.; Takahashi, A.; Kikuchi, Y.; Saito, S.; Shimomura, H.; Wanibuchi, Y.; Suzuki, T.; Kamatani, N.; Nakamura, Y. Association of VKORCl and CYP2C9 polymorphisms with warfarin dose requirements in Japanese patients. $J$. Hum. Genet., 2006, 51, 249-253.

[25] Isaza, C.; Henao, J.; Martínez, J.H.; Arias, J.C.; Beltrán, L. Phenotype-genotype analysis of CYP2C19 in Colombian mestizo individuals. BMC. Clin. Pharmacol., 2007, 7,6.

[26] Siddiqi, A.; Khan, D.A.; Khan, F.A.; Khaliq N.A. Impact of CYP2C9 genetic polymorphism on warfarin dose requirements in Pakistani population. Pak. J. Pharm. Sci., 2010, 4, 417-422.

[27] Adithan, C.; Gerard, N.; Vasu, S.; Balakrishnan, R.; Shashindran, C.H.; and Krishnamoorthy, R. Allele and genotype frequency of
CYP2C9 in Tamilnadu population. Eur. J Clin. Pharmacol., 2003, 59, 707-709.

[28] Jose, R.; Chandrasekaran, A.; Sam, S.S.; Gerard, N.; Chanolean, S.; Abraham, B.K.; Satyanarayanamoorthy, K.; Peter, A.; Rajagopal, $\mathrm{K}$. CYP2C9 and CYP2C19 genetic polymorphisms: frequencies in the south Indian population. Fundam. Clin. Pharmacol., 2005, 19, 101-105.

[29] Wang, S.L.; Huang, J.; Lai, M.D.; Tsai, J.J. Detection of CYP2C9 polymorphism based on the polymerase chain reaction in Chinese. Pharmacogenetics., 1995, 5, 37-42.

[30] Moridani, M.; Fu, L.; Selby, R.; Yun, F.; Sukovic, T.; Wong, B.; Cole, D., E. Frequency of CYP2C9 polymorphisms affecting warfarin metabolism in a large anticoagulant clinic cohort. Clin. Biochem., 2006, 36, 606-612.

Received: January 28, 2015

Revised: May 10, 2015

Accepted: May 11, 2015

(C) Tabari et al.; Licensee Bentham Open.

This is an open access article licensed under the terms of the Creative Commons Attribution Non-Commercial License (http://creativecommons.org/licenses/by-nc/3.0/) which permits unrestricted, non-commercial use, distribution and reproduction in any medium, provided the work is properly cited. 